\title{
EFFECT OF NONDESTRUCTIVE TESTING OF LAMINATIONS ON THE BENDING PROPERTIES OF GLULAM BEAMS MADE FROM LOURO -VERMELHO (Sextonia rubra)
}

\author{
Ricardo Faustino Teles ${ }^{1}$, Cláudio Henrique Soares Del Menezzi², Mário Rabelo de Souza ${ }^{3}$, Frederico de Souza ${ }^{4}$
}

(received: March 12, 2009; accepted: December 21, 2009)

\begin{abstract}
This work aims to assess the bending properties of glued laminated timber beams (glulam) manufactured with species louro-vermelho (Sextonia rubra). Laminations were nondestructively tested using the transverse vibration method ( $\left.\mathrm{E}_{\mathrm{Mlam}}\right)$. Then 10 glulam beams were manufactured and tested in static bending according to ASTM D 198 standard, having modulus of elasticity ( $\mathrm{E}_{\mathrm{M}}$ ), modulus of rupture $\left(\mathrm{f}_{\mathrm{M}}\right)$, and bending moment $(\mathrm{M})$ determined. The finished beams were also tested by the transverse vibration method $\left(\mathrm{E}_{\mathrm{Mvt}}\right)$. It was noted that the $\mathrm{E}_{\mathrm{Mvt}}$ value was only $2 \%$ lower than the $\mathrm{E}_{\mathrm{M}}$ value. Using laminations with a high modulus of elasticity did allow effective gain in stiffness. Therefore, results indicate that the transverse vibration method is a valid, reliable technique both for testing glulam laminations and for assessing stiffness in finished beams. Bending properties in glulam beams were influenced by the stiffness of constituent laminations.
\end{abstract}

Key words: Transverse vibration, glued laminated timber, static bending.

\section{EFEITO DA CLASSIFICAÇÃO NÃO DESTRUTIVA DAS LÂMINAS SOBRE AS PROPRIEDADES DE FLEXÃO DE VIGAS MLC PRODUZIDAS COM LOURO-VERMELHO (Sextonia rubra)}

RESUMO: Conduziu-se este trabalho, com o objetivo de avaliar as propriedades de flexão de vigas de madeira laminada colada $(M L C)$ produzidas com a espécie louro-vermelho (Sextonia rubra). As lâminas foram classificadas não destrutivamente pelo método de vibração transversal $\left(E_{\text {Mlam }}\right)$. Em seguida, 10 vigas de $M L C$ foram produzidas e ensaiadas em flexão estática, conforme a norma ASTM D 198 e determinados o módulo de elasticidade $\left(E_{M}\right)$, o módulo de ruptura $\left(f_{M}\right)$, e o momento fletor $(M)$. As vigas consolidadas foram ainda avaliadas pelo método de vibração transversal $\left(E_{M v t}\right)$. Foi observado que o $E_{M v t}$ apresentou valor somente $2 \%$ inferior $a E_{M}$. O uso de lâminas com elevado módulo de elasticidade proporcionou um ganho efetivo na rigidez das vigas de MLC. Dessa forma, os resultados indicam que o método de vibração transversal é uma técnica confiável e válida tanto para a classificação das lâminas de MLC, quanto para a avaliação da rigidez de vigas consolidadas. As propriedades de flexão de vigas de MLC foram influenciadas pela rigidez das lâminas que as compõem.

Palavras-chave: Vibração transversal, madeira laminada colada, flexão estática.

\section{INTRODUCTION}

In Brazil, the diversity of wood species is significant and has great potential awaiting exploration. However, selection and commercialization of only a few species contribute to unsuitable exploration of forest reserves, increasing pressure on those few forest species selected.

For suitable use of wood as structural material, knowledge of its strength and stiffness characteristics is indispensable. This should happen with all species, including alternative species whose potential is more promising, considering the wealth of use possibilities they offer.
Under this scenario, new manufacture technologies and research have been developed for use of wood in building construction. Glued laminated timber, also known in literature as glulam, can be an alternative for rational use of sawn wood as a possible, compatible solution for a vast range of structural problems. Glulam can be sized to meet geometric requirements not met previously by sawn wood, allowing use of wood pieces with transverse sections and smaller widths. The possibility of forming arches and structural components with curvatures and large hollow spaces has boosted the popularity of glulam structures both in Europe and in the US. Brazil only boasts a few manufacturing plants in the sector, yet a significant number

${ }^{1}$ Forest Engineer, PhD candidate in Forest Sciences/UnB, Assistant Professor at Faculdade da Terra de Brasília - Recanto das Emas, Área Especial, Quadra 203, Lote 32 S/N - 72610-300 - Brasília, DF, Brazil - rfteles@gmail.com

${ }^{2}$ Forest Engineer, Adjunct Professor - Departamento de Engenharia Florestal - Universidade de Brasília - Campus Universitário Darcy Ribeiro - 70904-970 - Brasília, DF, Brazil - cmenezzi@unb.br

${ }^{3}$ Physicist, Environmental Analyst - Laboratório de Produtos Florestais - Serviço Florestal Brasileiro - SCEN, Trecho 02 - 70818-900 Brasília, DF, Brazil - mario.souza@florestal.gov.br

${ }^{4}$ Forest Engineer, PhD candidate in Forest Sciences/UnB, Assistant Professor at Faculdades Integradas de Mineiros - Instituto de Ciências Agrárias - Rua 22, s/n, Setor Aeroporto - 75830-000 - Mineiros, GO, Brazil - frederico@fimes.edu.br 
of academic works have been developed over the past 10 years attempting to improve information available on the subject (FIORELLI 2005, GROHMANN \& SZÜCS 1998, NASCIMENTO et al. 2002, ZANGIÁCOMO 2003).

Moody \& Bohannan (1970) argue that the basic principle of glulam construction is to rationally distribute the selected laminations for best use of available material. According to Fagundes \& Szücs (1998) and Grohmann \& Szücs (1998), superior quality materials are positioned in portions subjected to greater stress demand whereas, likewise, inferior laminations are positioned in portions subjected to lesser stress demand. Arruda (1995) and Bodig \& Jayne (1993) presented studies on the contribution of the moment of inertia of each member lamination in relation to the total moment of inertia of the finished piece.

Zangiácomo (2003) studied four tropical wood species for use in glued laminated timber. The species found to be most compatible with desired characteristics for glulam use was cedrinho (Erisma sp.). The author assembled beams composed of graded laminations, both randomly and nonrandomly. The author observed that those assembled nonrandomly can show superior stiffness properties than those assembled randomly.

In the lamination testing process, visual and mechanical assessments are recommended. Visual testing is intended to evaluate and quantify knot presence and grain distortion in relation to the axis. The presence of these elements significantly reduces beam strength, leading to rupture which usually coincides with defect areas (COIADO \& DIAS 2004). In mechanical testing, nondestructive assessment is used to determine the longitudinal modulus of elasticity $\left(\mathrm{E}_{\mathrm{M}}\right)$ of laminations.

For Pellerin \& Ross (2002), nondestructive testing (NDT) is the science of identifying the physical and mechanical properties of a given material without changing its end use capability and using this information to ensure suitable application of the material. Most common methods of NDT of wood materials include transverse vibration, stress waves and ultrasound, and commonly used equipment includes stress wave timer, ultrasound and Ecomputer. With these testing processes, timber laminations can be graded according to quality class and then arranged in such way as to ensure improved resistance of its structural elements (TARGA et al. 2005).

Calil Junior \& Miná (2003) and Candian (2007) argue that the transverse vibration method provides reliable modulus of elasticity values and that it can be used on any type of timber, with any transverse section, and in glued laminated timber or wood panels.

According to the Brazilian Institute for the Environment and Renewable Natural Resources-IBAMA (2002), species Sextonia rubra (Mez) C. K. Allen-also known as louro-vermelho-belongs to the Lauraceae family and is found in some states of northern Brazil, including Amazonas, Pará, Amapá and Rondônia. It is graded as being medium density wood, with apparent density of $0.65 \mathrm{~g} / \mathrm{cm}^{3}$ at $12 \%$ of moisture content, and straight or reverse grain orientation and medium texture. Louro- vermelho has easy workability both with manual tools and machinery, allows good holding of nails and screws and is easily bonded, being used mainly in building construction to manufacture doorjambs, doors and windows, and to manufacture structures such as laths and secondary structural elements, being also used in furniture, raised platforms, frames, and ornamental laminates. Judging by physical and mechanical properties, the characteristics of louro-vermelho qualifies its timber for glulam beam manufacture. It is a commercial timber with good overall acceptance and affordable prices, being marketed in Distrito Federal in the form of planks and joists (IBAMA 1989, Instituto de Pesquisa Tecnológica - IPT 2003).

With the above in mind, this study aims to evaluate the bending properties of glued laminated timber beams made from louro-vermelho (Sextonia rubra) whose member laminations had been pretested using the transverse vibration method.

\section{MATERIAL AND METHODS}

\subsection{Wood material}

Eight planks of louro-vermelho wood (Sextonia rubra) were obtained from a timber market in Distrito Federal (DF) and visually identified by comparing it to the existing wood collection (Index Xylarium FPBw) of the Laboratório de Produtos Florestais - Serviço Florestal Brasileiro.

The planks were then sawn into boards sized $20 \mathrm{x}$ $250 \times 2100 \mathrm{~mm}$ on average (thickness $\mathrm{x}$ width $\mathrm{x}$ length) and air dried for 60 days until they reached $12 \%$ average moisture content. To produce laminations, the pieces were sawn into boards and then laminated into $20 \times 50 \times 2000 \mathrm{~mm}$ plies, to a final total of 52 plies after discarding some. The laminations were kept in an environmental chamber at $65 \pm 1 \% \mathrm{RH}$ and $20 \pm 3^{\circ} \mathrm{C}$ temperature to constant weight. All laminations were measured using a digital caliper and weighed using a digital scale accurate to 0.5 grs. 


\subsection{Nondestructive testing}

Laminations were nondestructively tested and graded by transverse vibration using a Metriguard E 340 Transverse Vibration E-Computer. The solid wood laminations were rested against tripods leaving a $1900 \mathrm{~mm}$ free span between ends, and vibration was induced by nonquantified manual impact to the center. With the system in motion, vibration frequency, weight and dynamic modulus of elasticity $\left(\mathrm{E}_{\mathrm{Mlam}}\right)$ were obtained directly by the equipment software. Figure 1 provides a visual step description of the test. After testing, the laminations were graded in decreasing order of stiffness and separated into groups of five laminations presenting close modulus of elasticity values and in decreasing order, which were then used to manufacture the glulam beams.

\subsection{Glulam beam assembly}

10 glulam beams were manufactured, each composed of five louro-vermelho laminations bonded together by a resorcinol-formaldehyde adhesive at a rate of $300 \mathrm{~g} / \mathrm{m}^{2}$, which, according to Teles (2009), is the optimum quantity of adhesive for best gluing results with this wood species. Adhesive was applied directly onto the wood ply in a single line, the amount being gauged by monitoring weight increase in the wood-adhesive aggregate using a digital scale accurate to $0.01 \mathrm{~g}$. With the help of a foam roller, the adhesive was then distributed over the entire surface.

After being bonded together, the beams were flattened to and average size of $100 \mathrm{~mm}$ high $\mathrm{x} 40 \mathrm{~mm}$ wide $\mathrm{x} 1900 \mathrm{~mm}$ long (Figure 2). The beams were assembled according to pregraded lamination stiffness and in such way that beam 1 was composed of the five laminations with highest $\mathrm{E}_{\mathrm{Mlam}}$ values, beam 2 with the next five, and so on until beam 10 , composed of the five laminations with lowest $\mathrm{E}_{\text {Mlam }}$ values.

Laminations were finally pressed into one-piece beams by a system composed of a $7150 \mathrm{~mm}^{2}$ hydraulic piston cylinder applying force on a 20-ton capacity load cell which was in turn distributed on the steel I-beam that was rested over the entire length of the beam. Load gauge was done using a digital controller coupled to the load cell. A constant pressure of $1.0 \mathrm{~N} / \mathrm{mm}^{2}$ was applied for 20 hours.
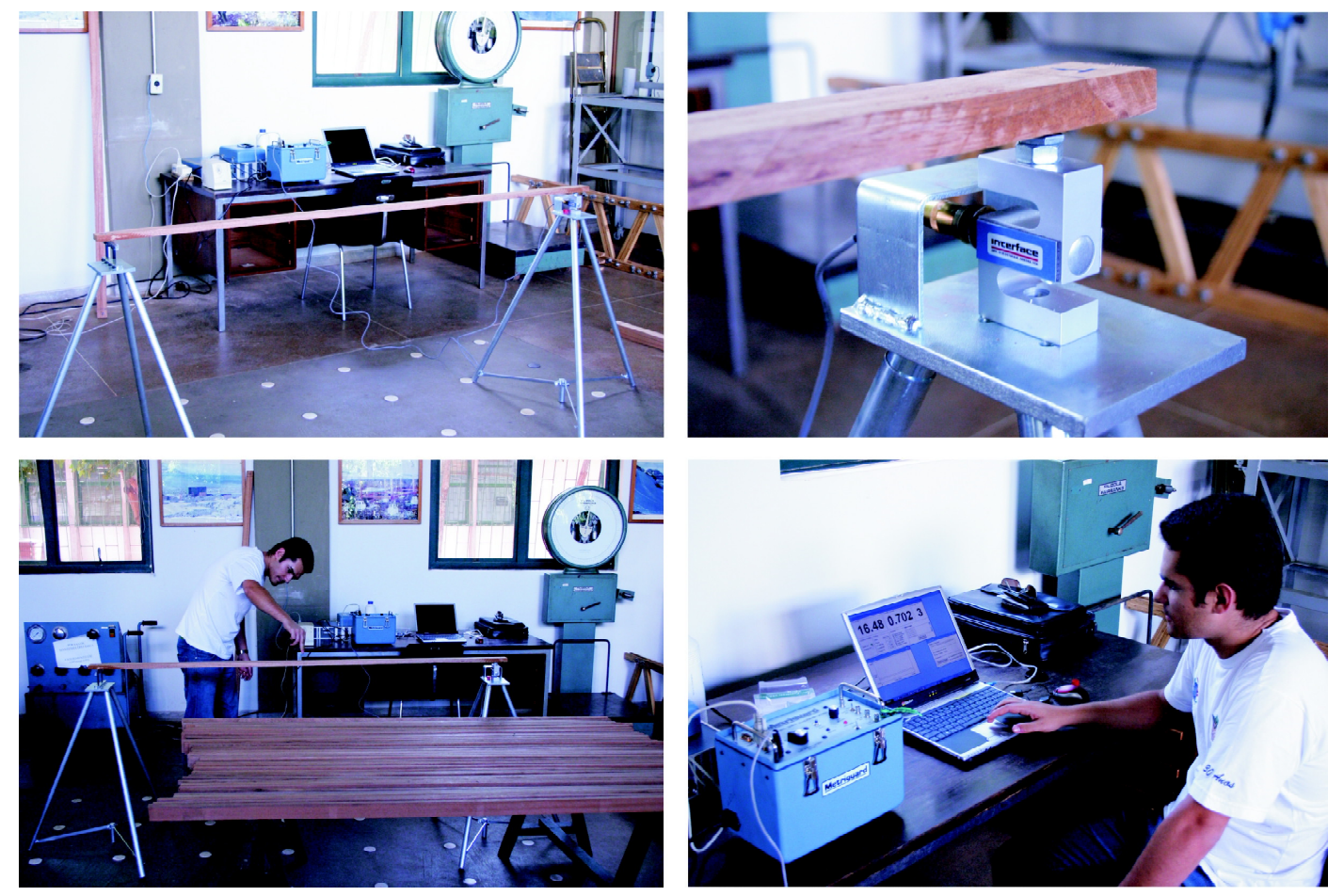

Figure 1 - Nondestructive testing by transverse vibration.

Figura 1 - Avaliação não destrutiva por meio da vibração transversal. 


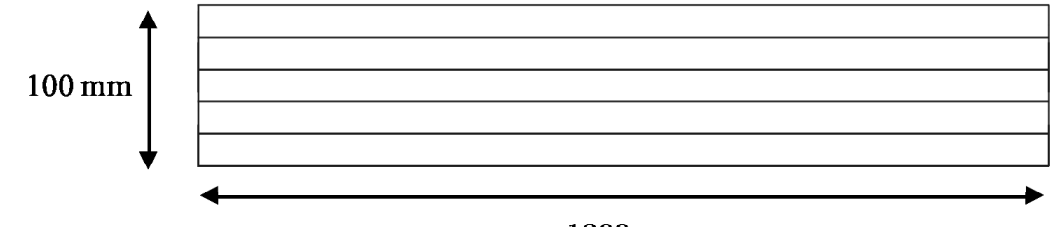

$1900 \mathrm{~mm}$

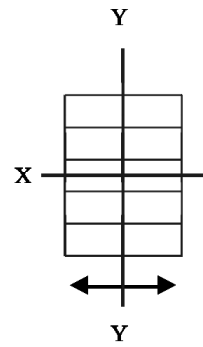

$40 \mathrm{~mm}$
Figure 2 - Size of glulam beams.

Figura 2 - Dimensão das vigas de MLC produzidas.

\subsection{Evaluation of bending properties}

Initially, the beams were nondestructively tested using transverse vibration with the pieces being positioned in the direction of least inertia. In this test, as with the laminations test, the beams were rested against tripods leaving a free span (L) of $1800 \mathrm{~mm}$, and vibration was induced by nonquantified manual impact to the center. With the system in motion, values of beam vibration frequency, weight and dynamic modulus of elasticity $\left(\mathrm{E}_{\mathrm{Mv}}\right)$ were obtained directly by the system software, with a total 10 readings per beam.

The beams were then tested for static bending in four points until rupture. The test followed guidelines described in ASTM D 198 standard (AMERICAN SOCIETY FOR TESTING AND MATERIALS-ASTM 1997), using an INSTRON universal testing machine at a loading speed of 6 $\mathrm{mm} / \mathrm{min}$ and moment about the $\mathrm{x}-\mathrm{x}$ axis. The free span (L) extended $1800 \mathrm{~mm}$ and the distance between load points was equal to $600 \mathrm{~mm}$. A MAHR MILLILAST 1082 dial indicator gauge accurate to $0.01 \mathrm{~mm}$ was positioned on the central portion of the piece to measure deflection directly. A laterally positioned bar was used to support the dial indicator, being placed parallel with the neutral line of the beam, with the dial indicator measuring deflection in the middle third of the beam subjected to pure bending. This experiment used deflection obtained by applying $4000 \mathrm{~N}$ of force, the dial indicator being removed after reaching this load value, leading to beam rupture. Modulus of elasticity $\left(\mathrm{E}_{\mathrm{M}}\right)$, modulus of rupture $\left(\mathrm{f}_{\mathrm{M}}\right)$ and bending moment $(\mathrm{M})$ were then computed according to Equations 1 to 3. Figure 3 provides a diagram of the procedure. After rupture, a sample sized $100 \times 40 \times 100 \mathrm{~mm}$ was taken to determine apparent density.

$$
E_{M}=\frac{4000 L a^{2}}{4 b h^{3} \delta}
$$

$$
\begin{gathered}
f_{M}=\frac{P_{r u p} L}{b h^{2}} \\
M=\frac{P_{r u p} L}{6}
\end{gathered}
$$

Where:

$a=$ distance between load points, $\mathrm{mm}$;

$b=$ beam width, $\mathrm{mm}$;

$E_{M}=$ modulus of elasticity, $\mathrm{N} / \mathrm{mm}^{2}$;

$f_{M}=$ modulus of rupture, $\mathrm{N} / \mathrm{mm}^{2}$;

$h=$ beam height, $\mathrm{mm}$;

$L=$ distance between beam supports (free span), $\mathrm{mm}$;

$M=$ bending moment, $\mathrm{N} * \mathrm{~mm}$;

$P_{r u p}=$ rupture load, $\mathrm{N}$.

\section{RESULTSAND DISCUSSION}

Table 1 outlines lamination positioning to form the glulam beams, and the composition of the ten beams, with respective modulus of elasticity values obtained by transverse vibration $\left(\mathrm{E}_{\mathrm{Mvt}}\right)$ and modulus of elasticity values obtained by the arithmetic mean of member laminations $\left(\mathrm{E}_{\mathrm{Mlam}}\right)$. It can be noted that $\mathrm{E}_{\mathrm{Mvt}}$ and $\mathrm{E}_{\mathrm{Mlam}}$ values decrease concomitantly from beam 1 to beam 10, demonstrating a close relationship between these two variables. Beams manufactured with stiffer laminations also presented greater final product stiffness.

Table 2 provides results of bending properties from static bending test and apparent density of glulam beams. A reduction is noted in $\mathrm{P}_{\text {rup }}, \mathrm{E}_{\mathrm{M}}$ and $\mathrm{f}_{\mathrm{M}}$ values from beam 1 to beam 10. A reduction occurs concomitantly in beam apparent density. A comparison between Table 1 and Table 2 results shows that as stiffness values determined nondestructively decrease $\left(\mathrm{E}_{\mathrm{Mlam}}\right.$ and $\left.\mathrm{E}_{\mathrm{Mvt}}\right)$, a gradual 


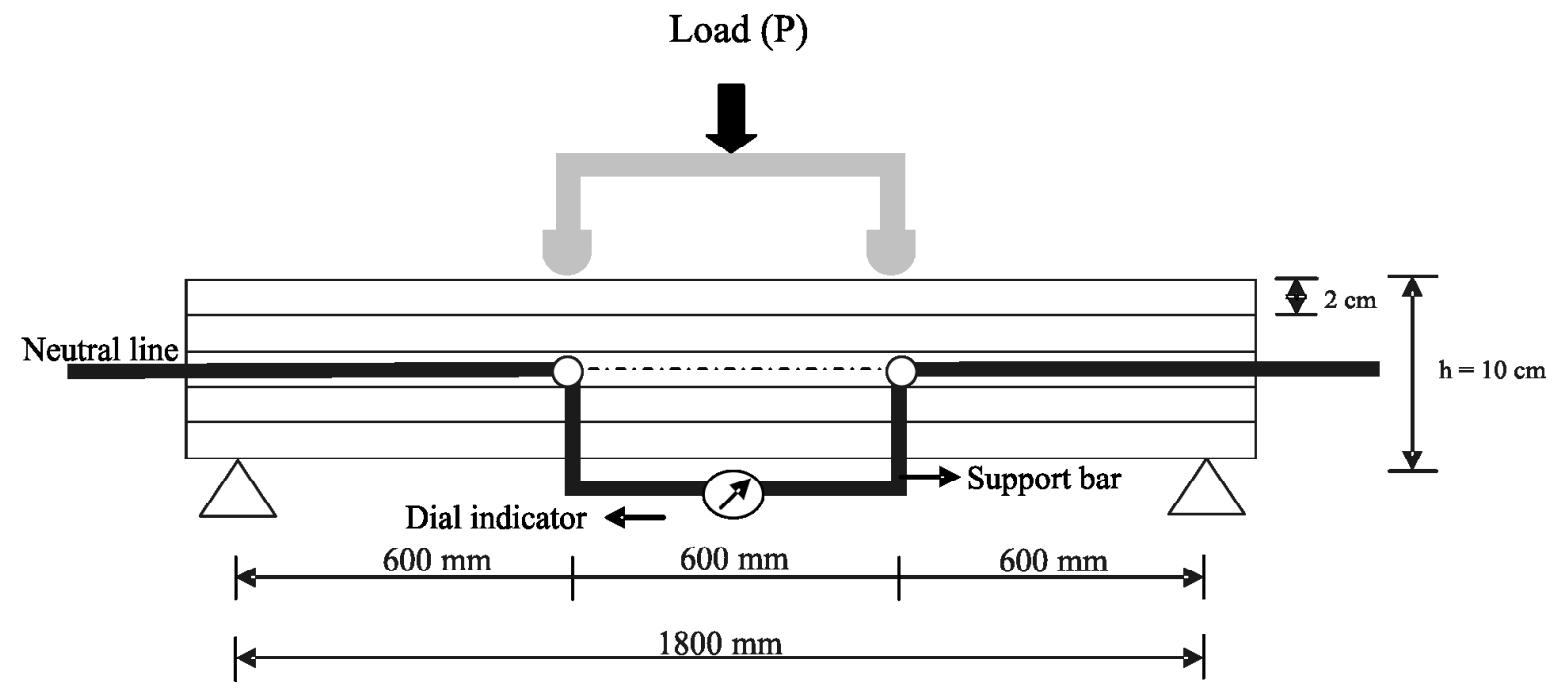

Figure 3 - Four-point static bending test.

Figura 3 - Ensaio de flexão estática de quatro pontos.

Table 1 - Nondestructive testing of laminations and beams, and composition of the 10 glulam beams.

Tabela 1 - Avaliação não destrutiva das lâminas e das vigas, e respectiva composição das 10 vigas MLC.

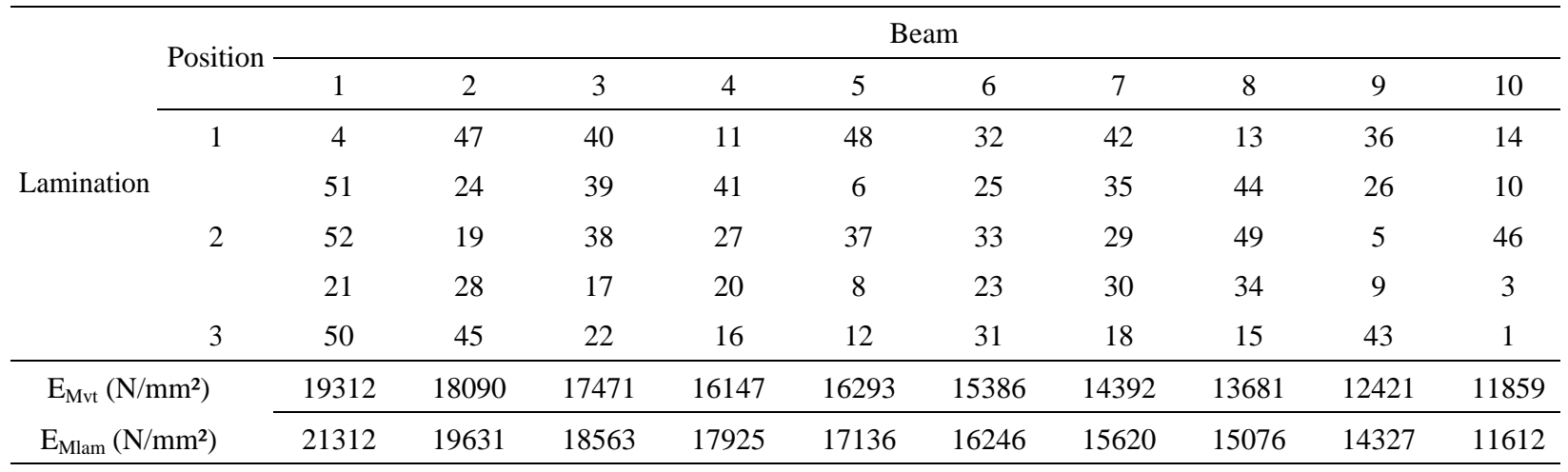

Where: $\mathrm{E}_{\mathrm{Mvt}}=$ modulus of elasticity by the transverse vibration method; $\mathrm{E}_{\mathrm{Mlam}}=$ modulus of elasticity by the arithmetic mean of laminations. Position 1 = upper side, $2=$ center lamina, $3=$ lower side.

reduction also occurs in bending properties determined destructively by static bending test.

Regression equations are presented in Figure 4 to illustrate relationships between $\mathrm{E}_{\mathrm{M}}, \mathrm{f}_{\mathrm{M}}$ and $\mathrm{E}_{\mathrm{Mvt}}$ and between $\mathrm{E}_{\mathrm{Mvt}}$ and $\mathrm{E}_{\mathrm{Mlam}}$. A high coefficient of determination is observed between $\mathrm{E}_{\mathrm{Mlam}}$ and $\mathrm{E}_{\mathrm{Mvt}}$, (Figure $4 \mathrm{C}$ ), indicating that individual grading of laminations indeed was reflected positively in final beam stiffness. Additionally, relationships between $\mathrm{E}_{\mathrm{Mvt}} \mathrm{xf}_{\mathrm{M}}$ (Figure $4 \mathrm{~B}$ ) and between $\mathrm{E}_{\mathrm{Mvt}} \times \mathrm{E}_{\mathrm{M}}$ (Figure $4 \mathrm{~A}$ ) proved highly significant, despite the lower coefficients of determination. It was noted that $\mathrm{E}_{\mathrm{Mvt}}$ and $\mathrm{E}_{\mathrm{Mlam}}$ values were very close, indicating low variability between the modulus of elasticity values of constituent laminations. This low variability can be explained by the fact that each beam was composed of laminations with close $\mathrm{E}_{\text {Mlam }}$ values, as obtained by the transverse vibration method.

It was observed that beam assembly according to quality of constituent laminations did provide stiffness gain, validating the proposal of lamination grading. 
Table 2 - Bending properties of glulam beams made from louro-vermelho.

Tabela 2 - Propriedades de flexão das vigas de MLC de louro-vermelho.

\begin{tabular}{cccccc}
\hline Beam & $\mathrm{P}_{\text {rup }}(\mathrm{N})$ & $\mathrm{E}_{\mathrm{M}}\left(\mathrm{N} / \mathrm{mm}^{2}\right)$ & $\mathrm{f}_{\mathrm{M}}\left(\mathrm{N} / \mathrm{mm}^{2}\right)$ & $\mathrm{M}(\mathrm{N} \cdot \mathrm{mm})$ & $\mathrm{DA}\left(\mathrm{g} / \mathrm{cm}^{3}\right)$ \\
\hline 1 & 19246.7 & 20285.9 & 82.6 & $5.8 \mathrm{E}+06$ & 0.71 \\
2 & 18511.0 & 18693.4 & 83.9 & $5.6 \mathrm{E}+06$ & 0.71 \\
3 & 17609.2 & 18853.3 & 79.6 & $5.3 \mathrm{E}+06$ & 0.70 \\
4 & 11225.3 & 16903.5 & 50.5 & $3.4 \mathrm{E}+06$ & 0.66 \\
5 & 18511.0 & 15362.4 & 83.9 & $5.6 \mathrm{E}+06$ & 0.69 \\
6 & 13912.9 & 13682.7 & 63.1 & $4.2 \mathrm{E}+06$ & 0.66 \\
7 & 15698.8 & 13853.9 & 66.9 & $4.7 \mathrm{E}+06$ & 0.65 \\
8 & 14375.7 & 15352.7 & 63.0 & $4.3 \mathrm{E}+06$ & 0.66 \\
10 & 10299.7 & 13375.2 & 44.5 & $3.1 \mathrm{E}+06$ & 0.59 \\
Coefficient of Variation $(\%)$ & 7321.4 & 11938.5 & 31.4 & $2.2 \mathrm{E}+06$ & 0.53 \\
\hline Mean & 14671.2 & 15830.2 & 64.9 & $4.4 \mathrm{E}+06$ & 0.66 \\
\hline
\end{tabular}

Where: $\mathrm{P}_{\text {rup }}=$ rupture load; $\mathrm{E}_{\mathrm{M}}=$ modulus of elasticity of beam; $\mathrm{f}_{\mathrm{M}}=$ modulus of rupture; $\mathrm{M}=$ bending moment; $\mathrm{DA}=$ apparent density.
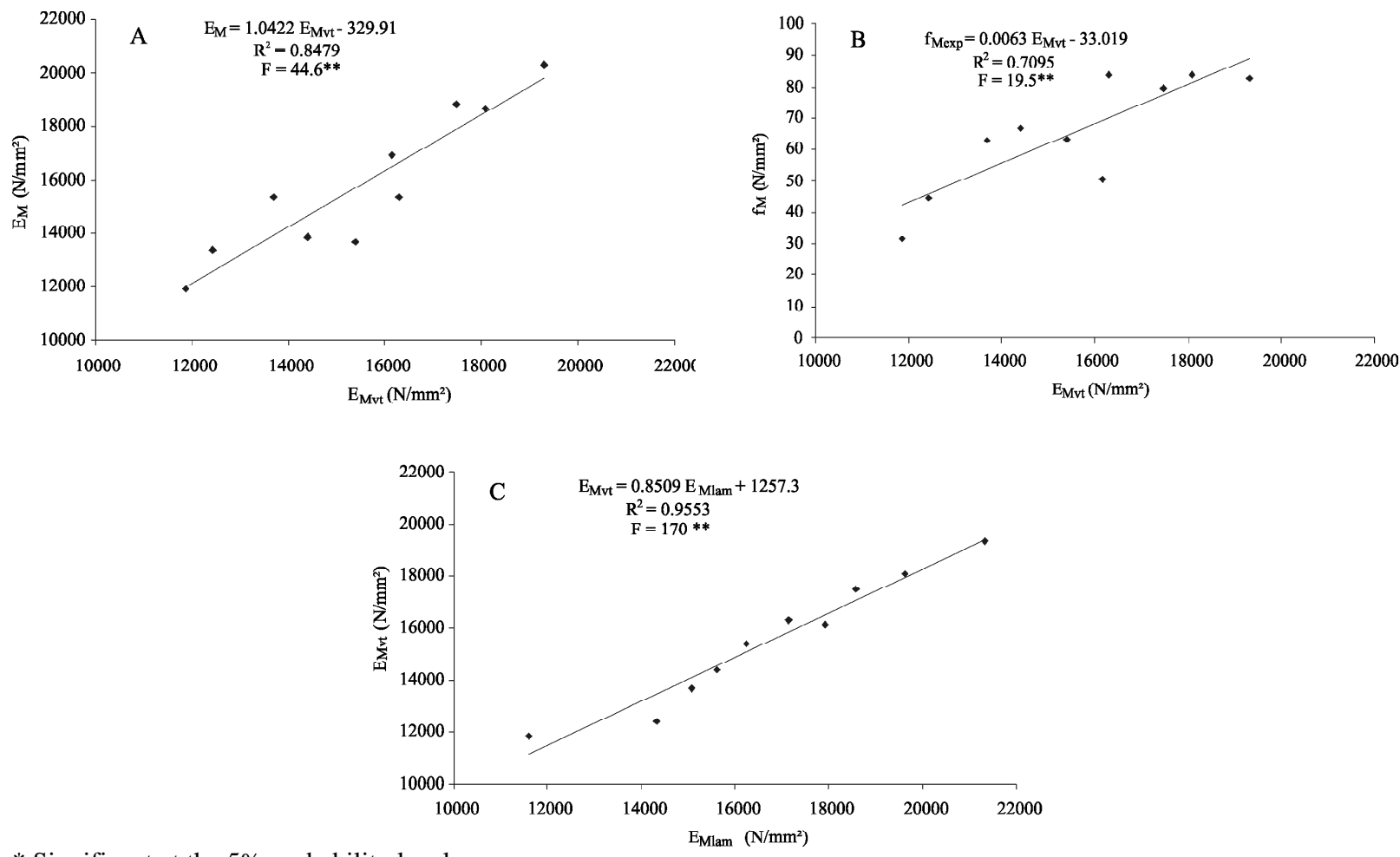

* Significant at the 5\% probability level.

* Significativo ao nível de $5 \%$ de probabilidade.

Figure 4 - Relationship between $\mathrm{E}_{\mathrm{M}}, \mathrm{f}_{\mathrm{M}}$ and $\mathrm{E}_{\mathrm{Mvt}}(\mathrm{A}$ and $\mathrm{B})$, and between $\mathrm{E}_{\mathrm{Mvt}}$ and $\mathrm{E}_{\mathrm{Mlam}}(\mathrm{C})$ for glulam beams made from louro-vermelho. Figura 4-Relação entre $E_{M}, f_{M} \operatorname{com} E_{M v t}\left(A\right.$ e B) e $E_{M v t} \operatorname{com} E_{\text {Mlam }}(C)$ para as vigas de MLC de louro-vermelho.

Cerne, Lavras, v. 16, n. 1, p. 77-85, jan./mar. 2010 
Also in Figure 4, $\mathrm{E}_{\mathrm{Mlam}}$ results indicate that the use directly of mean stiffness values of constituent laminations by the nondestructive method can be reflected in beam stiffness. Also, a significant relationship was noted between $\mathrm{E}_{\text {Mlam }}$ and $\mathrm{E}_{\mathrm{Mvt}}$, indicating that the transverse vibration method is a reliable technique that can be used to assess stiffness both in finished glulam beams and in constituent laminations.

Additionally, it was noted that overall $\mathrm{E}_{\mathrm{Mvt}}$ results agreed well with experimental $\mathrm{E}_{\mathrm{M}}$ values (Table 3), around $2 \%$ lower than experimental values.

Using laminations with high modulus of elasticity values allowed effective gain in glulam beam stiffness. Similar results were found by Nascimento et al. (2002), who observed that irregular grain orientation and knot presence in Pinus $\mathrm{sp}$ wood significantly reduce the rupture load. Results obtained in this work for beam 4 and beam 10 illustrate this assertion in that rupture occurred below the estimated maximum load, resulting in lower values of rupture stress and bending moment than the expected, as discussed next.

It was noted that apparent density, being one of the simplest parameters to define in the manufacturing process of glulam beams, to be an important characteristic of the final beam quality. This occurs because increasing apparent density values tend to derive stronger, stiffer beams. It should be noted that in this study this result is due to constituent laminations having close density values as well as close strength and stiffness properties, which is reflected in low beam variability.

According to Burdzik (1997) and Nascimento et al. (2002), inferior strength laminations are the ones that initiate the rupture process in the relevant tensioned area, as opposed to those undergoing rupture in areas with natural defects. Falk \& Colling (1995) evaluated this effect in glulam beams produced in Europe and USA and suggest that the mechanical quality grading of laminations subjected to greater tension is an indicator of strength properties against bending and seems to be an effective way of rating glulam beams. The authors further argue that the quality of constituent laminations directly affects the mechanical behavior of the finished beams.

Overall, ruptures started on the laminations of the tensioned area of the beam, and so the rupture of the last member lamination by parallel tension is a common occurrence, with propagation by shear stress. The bonding quality was considered satisfactory, with a low shearing rate in the glue-applied lamination. Fiorelli (2005) and Hernandez \& Moody (1996) argue that the rupture of a glulam beam usually starts in laminations positioned in the tensioned portion, particularly where some type of defect is present, including knots and interlocked fibers in relation to the axis. From this point, rupture propagates, usually through joints portions, causing the beam to collapse. Thus, bending strength in glulam beams is usually determined based on the strength of the relevant tensioned area.

Table 3 - Values and relationship between $\mathrm{E}_{\mathrm{Mvt}}$ and $\mathrm{E}_{\mathrm{M}}$.

Tabela 3 - Valores e relação entre de $E_{M v t}$ e $E_{M}$.

\begin{tabular}{|c|c|c|c|}
\hline Beam & $\mathrm{E}_{\mathrm{Mvt}}\left(\mathrm{N} / \mathrm{mm}^{2}\right)$ & $\mathrm{E}_{\mathrm{M}}\left(\mathrm{N} / \mathrm{mm}^{2}\right)$ & $\mathrm{E}_{\mathrm{Mvt}} / \mathrm{E}_{\mathrm{M}}$ Relationship \\
\hline 1 & 19312 & 20286 & 0,95 \\
\hline 2 & 18090 & 18693 & 0.97 \\
\hline 3 & 17471 & 18853 & 0.93 \\
\hline 4 & 16147 & 16904 & 0.96 \\
\hline 5 & 16293 & 15362 & 1.06 \\
\hline 6 & 15386 & 13683 & 1.12 \\
\hline 7 & 14392 & 13854 & 1.04 \\
\hline 8 & 13681 & 15353 & 0.89 \\
\hline 9 & 12421 & 13375 & 0.93 \\
\hline 10 & 11859 & 11939 & 0.99 \\
\hline Mean & 15505 & 15830 & 0.98 \\
\hline Standard Deviation & 2437 & 2758 & 0.07 \\
\hline Coefficient of Variation (\%) & $15.7 \%$ & $17.4 \%$ & $7.2 \%$ \\
\hline
\end{tabular}

Where: $\mathrm{E}_{\mathrm{Mvt}}=$ modulus of elasticity of beam by transverse vibration; $\mathrm{E}_{\mathrm{M}}=$ modulus of elasticity. 


\section{CONCLUSIONS}

The bending properties of glulam beams were significantly influenced by the stiffness of constituent laminations, which means that the use of stiffer laminations is reflected in stiffer, stronger glulam beams.

The transverse vibration method proved suitable for stiffness grading of both laminations and finished beams, allowing production of stiffer glulam beams.

\section{ACKNOWLEDGEMENTS}

To CAPES (Coordenação de Aperfeiçoamento de Pessoal de Nível Superior), for granting the scholarship to the first author.

To CNPq, through 'Edital Universal 2007' (Proc. 474737/2007-1), for fully sponsoring the work;

To the Laboratório de Produtos Florestais (LPF) for all the logistic support in beams production and mechanical testing.

To the Fundação de Tecnologia Florestal (FUNTEC), for technical and financial support throughout the project.

\section{BIBLIOGRAPHICAL REFERENCES}

AMERICAN SOCIETY FOR TESTING AND MATERIALS. ASTM D198: standard test methods of static tests of lumber in structural sizes. Philadelphia, 1997.

ARRUDA, H. A. C. Influência da classificação das lâminas em vigas de MLC. 1995. Dissertação (Mestrado em Engenharia Civil) - Universidade Federal de Santa Catarina, Florianópolis, 1995.

BODIG, J.; JAYNE, B. A. Mechanics of wood and wood composites. New York: V.N. Reinhold, 1993.

BURDZIK, W. M. G. Finger joint strength: a laminated beam strength predictor? South African Forestry Journal, Pretoria, n. 178, p. 39-45, 1997.

CALIL JUNIOR, C.; MINA, A. Vibração transversal: um método eficiente para a classificação de peças estruturais de madeira. Engenharia Agrícola, Campina Grande, v. 7, n. 2, p. 335-338, 2003.

CANDIAN, M. Estudo da classificação não destrutiva de peças serradas de espécies cultivadas no Brasil para uso em estrutura. 2007. 154 p. Dissertação (Mestrado) - Escola de Engenharia de São Carlos, Universidade de São Paulo, São Carlos, 2007.

Cerne, Lavras, v. 16, n. 1, p. 77-85, jan./mar. 2010
COIADO, B.; DIAS, A. A. Avaliação da resistência à tração paralela às fibras de peças de madeira de Pinus Sp com dimensões estruturais e classificadas visualmente. São Carlos: USP, 2004. Relatório de iniciação científica.

FAGUNDES, S. R.; SZÜCS, C. A. Composição racional de vigas de madeira laminada colada de Pinus. In: ENCONTRO BRASILEIRO EM MADEIRAS E EM ESTRUTURAS DE MADEIRA, 6., 1998, Florianópolis. Anais... Florianópolis: UFSC, 1998. v. 1.

FALK, R. H.; COLLING, F. Laminating effects in glued-laminated timber beams. Journal of Structural Engineering, v. 121, n. 12, p. 1857-1863, 1995.

FIORELLI, J. Estudo teórico e experimental de vigas de madeira laminada colada reforçadas com fibra de vidro. 2005. 108 p. Tese (Doutorado) - Escola de Engenharia de São Carlos, Universidade de São Paulo, São Carlos, 2005.

GROHMANN, S. Z.; SZÜCS, C. A. Vigas de madeira laminada colada com lâminas pré-classificadas de Eucalyptus grandis. In: ENCONTRO BRASILEIRO EM MADEIRAS E EM ESTRUTURAS DE MADEIRA, 6., 1998, Florianópolis. Anais... Florianópolis: UFSC, 1998. v. 1.

HERNADEZ, R.; MOODY, R. C. Analysis of glulam timber beams with mechanically graded (E-rated) outer laminations. In: INTERNATIONAL WOOD ENGINEERING CONFERENCE, 1996, New Orleans. Proceedings... Boton Rouge: Lousiana State University, 1996. v. 1, p. 144-150.

INSTITUTO BRASILEIRO DO MEIO AMBIENTE E DOS RECURSOS NATURAIS RENOVÁVEIS. Madeiras da Amazônia: descrição do lenho de 40 espécies ocorrentes na floresta nacional do Tapajós. Brasília: Ibama-LPF, 1989. $156 \mathrm{p}$.

INSTITUTO BRASILEIRO DO MEIO AMBIENTE E DOS RECURSOS NATURAIS RENOVÁVEIS. Madeiras tropicais brasileiras. 2. ed. Brasília: Ibama-LPF, 2002. 152 p.

INSTITUTO DE PESQUISA TECNOLÓGICA DO ESTADO DE SÃO PAULO. Madeira: uso sustentável na construção civil. São Paulo: IPT, 2003. 59 p. 
MOODY, R. C.; BOHANNAN, B. Flexural properties of glued-laminates souther pine beams with laminatios positioned by visual-stiffness criteria. Madison: Forest Produtcs Laboratory, 1970.

NASCIMENTO, A. M.; DELLA LUCIA, R. M.; BAETA, F. C. Comportamento de vigas retas em MLC com emendas de topo e bisel: parte I. Floresta e Ambiente, Seropédica, v. 9, n. 1, p. 63$71,2002$.

PELLERIN, R. F.; ROSS, J. R. Nondestructive evaluation of wood. Madison: USDA, 2002.

TARGA, L. A.; BALLARIN, A. W.; BIAGGIONI, M. A. M. Avaliação do módulo de elasticidade da madeira com uso de método não-destrutivo de vibração transversal. Engenharia agrícola, Jaboticabal, v. 25, n. 2, p. 291-299, maio/ago. 2005.

TELES, R. F. Propriedades tecnológicas de vigas de madeira laminada colada produzidas com louro vermelho (Sextonia rubra). 2009. 118 p. Dissertação (Mestrado em Ciências Florestais) - Universidade de Brasília, Brasília, 2009.

ZANGIÁCOMO, A. L. Emprego de espécies tropicais alternativas na produção de elementos estruturais de madeira laminada colada. 2003. 78 p. Dissertação (Mestrado em Engenharia) - Escola de Engenharia de São Carlos, Universidade de São Paulo, São Carlos, 2003. 